Ashil: Jurnal Pendidikan Anak Usia Dini

Vol. 1 No. 1, April 2021. e-ISSN: 2776-4117

https://doi.org/10.33367/piaud.v1i1.1572

Journal Ashil

Submitted: $\quad$ Revised:

11-02-2021

22-03-2021

Accepted:

Published:

$17-04-2021$

24-04-2021

\title{
Pentingnya Sains dan Peran Orangtua dalam Pengajaran Sains Kepada Anak di Rumah
}

\author{
Wuni Arum Sekar Sari \\ Institut Agama Islam Tribakti \\ wuniarums@gmail.com
}

\begin{abstract}
Abstrak
Tujuan penelitian ini adalah untuk mengetahui pentingnya pengajaran sains sejak dini serta peran orangtua dalam pengajaran sains selama dirumah, serta aktivitas apa yang bisa dilakukan oleh anak usia TK, atau anak usia 5-7 tahun untuk mempelajari sains selama dirumah. Hal ini terjadi karena selama masa pandemi COVID-19 anak sekolah dianjurkan untuk belajar di rumah. Selama anak belajar dirumah banyak hal yang dapat diajarkan ke anak salah satunya yaitu sains. Penelitian ini termasuk penelitian kualitatif dimana data diperoleh berdasarkan hasil studi pustaka. Hasil dari penelitian bahwa peran orangtua sangat penting selama kegiatan belajar di rumah. Rumah adalah tempat yang tepat bagi orang tua untuk mulai mendalami sains bersama anak. Ada banyak kegiatan yang dapat dilakukan dalam mengajarkan sains kepada anak, seperti menanyakan berbagai pertanyaan berhubungan dengan sains dan melatih keterampilan tangan. Anakanak belajar dengan melakukan, dengan mencoba ide-ide baru dan menantang. Hal ini tidak hanya terjadi di sekolah, tetapi orangtua juga dapat membantu anak belajar dengan memberinya pengalaman belajar sains yang aman dan menyenangkan selama di rumah.
\end{abstract}

Kata kunci: Pandemi COVID-19, Pembelajaran Sains, Belajar dari Rumah

\begin{abstract}
The purpose of this study was to determine the importance of teaching science from an early age and the role of parents in teaching science at home, as well as what activities kindergarten children or children aged 5-7 years can study science at home. This happened because during the COVID-19 pandemic, children's schools were encouraged to study at home. As long as children learn at home, many things can be taught to children, one of it is science. This research is a qualitative research, where data is obtained based on the results of literature studies. The results of the study show that the role of parents is very important during learning activities at home. Home is the right place for parents to start exploring science with their children. There are many activities that can be done in teaching science to children, such as asking questions related to science and practicing hand skills. Children learn by doing, by trying new and challenging ideas. This not only happened at school, but parents can also help their children to
\end{abstract}


learn by providing them with a safe and enjoyable science learning experience while at home.

Keywords: Pandemic COVID-19, Learning Science, Learning from Home

\section{PENDAHULUAN}

Perkembangan dan pertumbuhan yang terjadi pada anak akan optimal jika adanya peran serta dari orang tua. Karena orang tua termasuk guru pertama bagi anak, selain itu mengoptimalkan tumbuh kembang, kecerdasan anak, arahan, masukan, serta memfasilitasi kebutuhan anak untuk mencapai cita-citanya. Orang tua memiliki tanggung jawab terhadap pendidikan anak. Yenni Kartikasari (2020) menyatakan dalam penelitiannya bahwa perhatian orang tua terhadap kegiatan belajar anak sangat berpengaruh terhadap minat anak untuk belajar di manapun berada, di rumah maupun di sekolah.

Selama masa pandemi yang sudah melanda hampir seluruh dunia sejak Desember 2019 hingga saat ini tengah digemari dengan virus baru yang bernama COVID-19 maka pembelajaran dilakukan secara daring di rumah tidak di tatap muka di sekolahan.

Penyebarannya juga cepat, mulai dari kota Wuhan di China, kini menyebar ke seluruh dunia. Infeksi COVID-19 yang berujung pada penularan dari kasus ke kasus memiliki interval serial yang lebih pendek dari SARS sehingga penyebarannya cepat. Penyebaran virus semakin cepat, sehingga angka kematian di Indonesia semakin meningkat. COVID-19 adalah virus RNA untai positif dengan gejala demam, kelelahan, dan batuk mirip dengan kasus infeksi pada SARS-Cov dan MERS-CoV.

Pemerintah menetapkan Keputusan Presiden Nomor 7 Tahun 2020, menanggapi wabah ini. Soal Satgas Percepatan Penyakit Virus Corona 2019, serta melakukan berbagai tindakan darurat termasuk instansi pemerintah melakukan Work From Home (WFH) bagi pegawai yang diikuti oleh instansi swasta yang menerapkan kebijakan yang sama bagi seluruh pegawai (Putri, 2020). Bahkan Menteri Pendidikan dan Kebudayaan mengeluarkan dua surat edaran, Nomor 2 tahun 2020 tentang Pencegahan dan Penanganan COVID-19 di lingkungan Kementerian Pendidikan dan Kebudayaan, dan Nomor 3 tahun 2020 tentang 
pencegahan Penyakit Virus Corona COVID-19 di Unit Pendidikan. Surat edaran himbauan terkait pencegahan penularan penyakit coronavirus 2019, pada butir 2 (dua) disebutkan bahwa pengalihan setiap kegiatan pembelajaran dari sekolah ke rumah bagi siswa PAUD hingga tingkat Universitas. Dinas Pendidikan dan Kepala Sekolah diminta untuk memastikan pelaksanaan pembelajaran yang efektif dari rumah dan tidak bepergian atau pindah rumah (Putri, 2020).

Kebijakan perpindahan kegiatan belajar dari sekolah ke rumah berimplikasi pada perubahan model pembelajaran, dari tatap muka menjadi online. Guru memanfaatkan aplikasi seperti Google Classroom, Zoom, dan fasilitas lainnya. Menurut (Hartley, 2001) yang menyatakan e-learning adalah suatu belajar mengajar yang memungkinkan yang disampaikan melalui bahan ajar ke peserta didik menggunakan media internet, media jaringan komputer, dan internet. Hal ini sependapat dengan penelitian Darin E. Hartley (Hartley, 2001)

Teknologi yang lebih kritis untuk pendidikan akan lebih banyak penelitian untuk memahami penerapannya. Dalam beberapa penelitian, pembelajaran online memiliki beberapa keunggulan diantaranya fleksibilitas yang memungkinkan siswa untuk menyesuaikan dengan kendala yang dihadapi selama pembelajaran online baik dari segi waktu maupun tempat. Selain itu, siswa juga dapat memilih pengalaman belajar yang sesuai dengan karakteristiknya.

Sekolah, guru, dan orangtua hendaknya memberikan dukungan sosial di rumah agar anak nyaman dalam belajar. Komponen tersebut harus mendorong perubahan pemodelan di lingkungan rumah, dan ini merupakan bagian penting dari program intervensi awal untuk meningkatkan pengasuhan anak dengan menilai kemungkinan dampak perubahan yang didorong oleh kebijakan dalam lingkungan belajar di rumah. Salah satu tantangan home learning dengan memanfaatkan pembelajaran online adalah bagaimana model tersebut diteruskan kepada keluarga dengan pendapatan ekonomi minimal.

Peran orangtua sangat penting di masa sekarang. Orangtua tidak hanya perlu mengajar berhitung, membaca, menulis saja. Ada materi lain yang harus disampaikan oleh guru dan juga orangtua di rumah, yaitu Sains. Pengalaman sains yang menarik memungkinkan untuk pengembangan pemikiran ilmiah (Iftitah, 
2020). Mendukung anak-anak saat mereka mengembangkan pemikiran ilmiah selama masa kanak-kanak dapat menuntun anak-anak untuk dengan mudah mentransfer keterampilan berpikir mereka ke domain akademis lain yang dapat mendukung pencapaian akademik dan rasa kemanjuran diri mereka (Winarni, 2017).

Ada beberapa alasan untuk mulai mengajar sains pada masa anak usia dini. Pertama, anak-anak memiliki kecenderungan alami untuk senang mengamati dan berpikir tentang alam (Nugraha, 2017). Anak-anak kecil termotivasi untuk menjelajahi dunia di sekitar mereka, dan pengalaman sains awal dapat memanfaatkan kecenderungan ini (Fadlilah, 2020). Keterlibatan yang sesuai dengan perkembangan, dengan pengalaman belajar sains yang berkualitas, sangat penting untuk membantu anak-anak memahami dunia, mengumpulkan dan mengatur informasi, menerapkan dan menguji gagasan, dan mengembangkan sikap positif terhadap sains (Prasetyo, Implementasi Pembelajaran Sains untuk Anak Usia Dini dalam Menghadapi Masyarakat Ekonomi Asean (MEA), 2017). Pengalaman belajar sains yang berkualitas memberikan dasar yang kokoh untuk perkembangan selanjutnya dari konsep ilmiah yang akan dihadapi anak-anak sepanjang kehidupan akademis mereka. Landasan ini membantu siswa untuk membangun pemahaman konsep sains utama dan memungkinkan pembelajaran masa depan dari ide yang lebih abstrak (Mahmudah, 2017).

Penelitian ini bertujuan untuk mengetahui tentang sains pada anak di rumah. Penelitian ini akan membahas tentang pembelajaran sains pada usia dini dan aktivitas yang dapat dilakukan di rumah untuk belajar sains.

TINJAUAN LITERATUR

Konsep Dasar Sains

Secara alami, anak usia 10 tahun ke bawah cenderung untuk selalu mencari jawaban dari pertanyaan- pertanyaan sederhana yang mereka miliki. Pertanyaanpertanyaan yang sederhana tersebut lebih bersifat implikasi dari karakter alami dalam rangka pemenuhan rasa ingin tahu akan segala fenomena yang mereka temukan di dalam kehidupan sehari-hari (Bredekamp, 1993). Berkaitan dengan hal tersebut, proses pembelajaran sains untuk mereka harus disamakan dengan 
karakter alami usianya. Artinya, pembelajaran sains untuk anak usia sekolah dasar tidak sama dengan bidang studi sains bagi siswa sekolah lanjutan atau yang lebih tinggi. Bertolak belakang kemudian muncul banyak pertanyaan.

Sains bagi anak bukan sesuatu yang kompleks, rumit, atau banyak, tetapi merupakan bentuk pemikiran yang sederhana. Bagi anak, sains bukan serangkaian kegiatan identifikasi suatu senyawa kimia yang kompleks, sebuah sarang lebah yang telah ditinggal penghuninya, sebuah biji tumbuhan, atau setangkai bunga ros, atau sains bukan sesuatu yang bersifat hit and miss. Sains bagi mereka, bukan untuk menghafal nama bagian-bagian tubuh serangga, atau bagian-bagian dari suatu bunga; juga tidak untuk belajar mengidentifikasi 20 macam tumbuhtumbuhan, 20 macam serangga, 20 macam bunga, atau 20 macam hal lainnya. Sains merupakan bentuk pembelajaran dari masalah-masalah yang ditemukan di manapun di dalam lingkungan kehidupannya sehari-hari. Lebih jelas lagi dapat dijelaskan, bahwa sains anak adalah suatu bentuk pembelajaran tentang lingkungan alaminya.

Sains untuk anak bukan ilmu kimia, fisika, biologi, astronomi, atau geologi. Kontennya memang berkaitan erat dengan bidang-bidang ilmu tersebut di atas, namun bagi mereka, sains merupakan suatu bentuk pembelajaran tentang masalah-masalah yang datang dan sesuai dengan pemikiran serta rasa ingin tahunya, maka dengan tingkat pertumbuhan dan perkembangan berpikirnya (Osborne \& Freyberg, 1994). Misalnya: apa yang menyebabkan angin bertiup? Apa yang membentuk awan?. Mereka selalu berusaha untuk mengetahui jawaban dari pertanyaan-pertanyaan tersebut, dan proses penemuan jawaban dari pertanyaan-pertanyaan tadi, adalah sains bagi anak.

Sains untuk anak, tidak selalu harus bersifat teknis dan terperinci dan detail tidak, karena anak usia di bawah 10 tahun tidak mudah untuk mengetahui sesuatu dengan cara ceramah atau penjelasan seperti itu. namun sains untuk mereka harus lebih bersifat pemberian dasar-dasar pengetahuan untuk mengakomodasikan sifat curiositynya yang timbul dari pertanyaan-pertanyaan: bagaimana (how), kapan (when), dan (where), dan apa (what) tentang sesuatu yang terjadi di lingkungan 
sekitar dirinya setiap hari (Osborne \& Freyberg, 1994). Itulah sebenarnya sains bagi mereka.

Anak-anak usia di bawah sepuluh tahun, umumnya tidak memerlukan istilahistilah teknis, rumus-rumus, dan penjelasan-penjelasan yang sangat dalam dan lengkap, karena hal itu semua, akan mengikuti kemudian (Kami \& De Vries, 1993). Tetapi perlu diingat, tatkala anak menginjak usia 10 tahun, mereka membutuhkan kepuasan lebih dari hal-hal yang sudah diketahuinya. Mereka membutuhkan sesuatu yang bisa memperluas rasa ingin tahu, memelihara interes, dan memacu antusiasnya dari segala proses pembelajaran yang dialaminya (Bredekamp,1993). Dengan kata lain, sains semacam inilah sebenarnya yang sesuai, dan diinginkan oleh anak.

Peran Orang Tua

Orang tua memiliki peran yang sangat besar dalam pendidikan anak. Orang tua sebagai guru pertama bagi anaknya. Dindin Jamaludin dalam Lilia Kusumaningrum (2019) menyatakan bahwa orang tua adalah sosok yang bisa ditentukan dalam kualitas kehidupan anak. Selain itu dalam penelitian Lilia Kusumaningrum (2019) menjelaskan bahwa orang tua merupakan guru serta sekolah pertama bagi anak. Orang tua bisa dijadikan pendidik serta memberikan pendidikan kepada anaknya baik rohani, jasmani, maupun sosial dan emosional. Anak membutuhkan pengawasan serta bimbingan yang tepat untuk bisa mengembangkan potensi secara optimal dan tumbuh dengan sehat.

Kemudian sejalan dengan penelitian Rahmawati dalam Agustin Lilawati (2020) menyatakan bahwa pengasuhan adalah sebuah proses adanya komunikasi yang terjalin antara anak dan orang tua untuk memperoleh pertumbuhan dan perkembangan yang optimal bagi anak.

Kegiatan yang dilakukan dengan memberikan rangsangan seperti perhatian dan kasih sayang yang tulus serta kehangatan, mengoptimalkan penggunaan indera anak untuk memperoleh pengalaman nyata, memberikan sentuhan, pelukan, senyuman dan sebagainya.

Dari beberapa penjelasan diatas penulis dapat menyimpulkan bahwa orang tua sebagai figur utama dan terdekat bagi anak mempunyai peran dalam 
mengasuh, membimbing, membina, melindungi, dan mendidik anaknya dengan layak. Peranan orang tua menjadikan anak tumbuh dan berkembang secara maksimal. Untuk itu orang tua harus bisa mengenali perkembangan dan kebutuhan anak.

\section{METODE}

Penelitian ini menggunakan metode penelitian kualitatif dengan pendekatan tinjauan sistematis literatur yang relevan dengan topik penelitian. Menurut Camry (2002), pendekatan tinjauan sistematis adalah pendekatan studi literatur yang bertujuan untuk mengidentifikasi, mengumpulkan, menilai secara kritis, dan mensintesis hasil penelitian sebelumnya yang relevan dengan topik tertentu. Hasil sintesis ini digunakan secara khusus untuk mendeskripsikan dan membahas masalah yang dibahas dalam artikel ini. Proses review sistematis ini dimulai dengan mencari literatur yang relevan dengan pembahasan terkait topik.

\section{HASIL DAN PEMBAHASAN}

Pembelajaran Sains Anak Usia Dini

Sains adalah pengetahuan yang sistematis atau tersusun secara teratur, berlaku umum dan berupa kumpulan suatu hasil observasi dan eksperimen (Nugraha, 2005). Pengertian sains untuk anak usia dini adalah bagaimana memahami sains berdasarkan sudut pandang anak. Karena jika kita memandang dimensi sains dari kacamata anak, maka akan berimplikasi pada kekeliruan dalam menentukan hakikat sains bagi anak usia dini yang berdampak cukup signifikan terhadap pengembangan pembelajaran sains itu sendiri kepada mereka.

Hal tersebut tentunya secara langsung maupun tidak langsung akan berdampak pula pada proses dan produknya yaitu anak-anak itu sendiri. Sains untuk anak usia dini menurut Carson yang dikutip oleh Nugraha (2005) sains bagi anak-anak adalah segala sesuatu yang menakjubkan, sesuatu yang ditemukan, dan dianggap menarik serta memberi pengetahuan atau merangsangnya untuk mengetahui dan menyelidikinya. 
Materi pengenalan sains yang sesuai untuk anak TK atau prasekolah (usia 4-6 tahun) antara lain: (1) mengenal gerak, misal: menggelinding dan bentuk benda; (2) mengenal benda cair, misal: percobaan benda tenggelam, terapung, benda larut dan tidak larut; (3) mengenal timbangan (neraca); (4) bermain gelembung sabun (5) pencampuran warna; (6) proses pertumbuhan; (7) percobaan dengan magnet, dan lain-lain (Sukapti et al., 2015).

Adapun keterampilan proses sains bagi anak usia dini adalah keterampilan proses sains dasar yang meliputi beberapa kemampuan sebagai berikut (Aisah, 2012): (1) Keterampilan mengamati yaitu keterampilan anak dalam melibatkan semua alat indra untuk menyatakan sifat yang dimiliki oleh suatu benda atau objek. (2) Keterampilan membandingkan yaitu keterampilan anak melihat persamaan dan perbedaan dari objek atau benda yang diamati sehingga memperoleh perbandingan. (3) Keterampilan mengklasifikasikan yaitu kemampuan anak dalam mengelompokkan benda atau objek berdasarkan sifat yang diamati dan dibandingkan. (4) Keterampilan mengukur yaitu kemampuan anak mengukur atau menilai objek atau benda. (5) Keterampilan menduga yaitu kemampuan anak memprediksi atau memperkirakan suatu kejadian. (6) Keterampilan mengkomunikasikan yaitu kemampuan anak menyampaikan informasi yang diperoleh.

Pentingnya Pembelajaran Sains Bagi Anak

Pembelajaran sains bagi anak bukanlah aktivitas pengenalan dan pengajaran terkait konsep-konsep sains tertentu pada anak semata, namun merupakan suatu upaya yang digunakan untuk menstimulasi aspek perkembangan dan memaksimalkan potensi yang ada dalam diri anak (Gross, 2012).

Menurut Worms, Shadow dan Whirlpools dalam Halverson (2007) menyatakan bahwa pentingnya pembelajaran sains untuk anak antara lain mampu memupuk rasa percaya diri anak di dalam lingkungannya, memberikan pengalaman penting secara langsung pada anak, mengembangkan konsep dasar pengetahuan alam, meningkatkan kemampuan mengamati, memperoleh kesempatan untuk menggunakan material yang biasa digunakan dalam 
pembelajaran sains, sehingga anak mulai terbiasa sejak dini, memperoleh bantuan dalam memecahkan masalah, mendapat kesempatan untuk menstimulasikan rasa ingin tahu mereka dan mendapatkan kesempatan untuk bereksplorasi, mengembangkan kemampuan sensori, fisik, intelektual, emosional, spiritual, dan sosial, serta mengembangkan kemampuan berbahasa melalui penambahan kosakata ketika anak melakukan kegiatan bertanya dan menjawab pertanyaan. Uraian tersebut menjelaskan tentang pentingnya pembelajaran sains bagi anak, sehingga sains mendapatkan posisi yang penting bagi stimulasi tumbuh kembang anak sejak dini.

Pentingnya Sains dalam Pendidikan Anak Usia Dini

Sepakat akan semua generasi masa depan bangsa Indonesia, diharapkan memiliki pengetahuan tentang sains. Studi penelitian dalam psikologi perkembangan dan kognitif menunjukkan bahwa efek lingkungan penting selama tahun-tahun awal perkembangan, dan kurangnya rangsangan yang dibutuhkan dapat mengakibatkan perkembangan anak tidak mencapai potensi sepenuhnya. Oleh karena itu tidak berarti bahwa guru harus memaksa anak didik untuk bisa memenuhi ruang-ruang kosong serta dipenuhi dengan fakta-fakta di dalam pemikirannya serta pendapatnya.

Namun guru harus membantu anak didik belajar untuk menggeneralisasi. Pengetahuan dan keterampilan tersebut dapat mereka manfaatkan untuk menginterpretasikan masalah-masalah yang ada di lingkungannya. Dengan demikian, pendidikan sains pada anak usia dini sangat penting untuk banyak aspek perkembangan anak, dan peneliti menyarankan pendidikan sains harus dimulai selama tahun-tahun awal sekolah.

Pembelajaran sains anak usia dini penting untuk mengatasi kesenjangan prestasi dalam kinerja sains. Meskipun kesenjangan prestasi dalam sains perlahanlahan menyempit, kesenjangan tersebut tetap ada di seluruh tingkat kelas dan waktu sehubungan dengan ras / etnis, status sosial ekonomi (SES), dan jenis kelamin (Dahl, 2018). Ini sejalan dengan pendapat Barlia (2006) yang menyatakan erat kaitannya dengan lingkungan alam sekitar merupakan salah satu bagian dari 
alat yang akan membawa orang tersebut menjadi orang berpengetahuan. Menurut Dahl (2018), kesenjangan prestasi dalam sains sebagai "sangat kongruen dari waktu ke waktu dan lintas studi dan kesenjangan prestasi ini terlihat jelas di awal sekolah. Kesenjangan dalam pendaftaran untuk kursus sains, jurusan perguruan tinggi, dan pilihan karir juga tetap ada di seluruh kelompok ras / etnis, SES, dan jenis kelamin (National Science Foundation, 2002). Para sarjana telah mengaitkan kesulitan awal dalam sains sekolah dengan keputusan siswa untuk tidak mengejar gelar lanjutan dan karir di bidang sains (Venkadasalam, V., Larsen, N., \& Ganea, P., 2019).

Pengajaran sains yang buruk pada anak usia dini berkontribusi pada sikap dan kinerja siswa yang negatif, dan masalah ini terus berlanjut hingga tahun-tahun sekolah menengah dan atas. Eshach dan Fried (2005) menyarankan pengalaman sains awal yang positif membantu anak-anak mengembangkan konsep dan penalaran ilmiah, sikap positif terhadap sains, dan landasan yang lebih baik untuk konsep ilmiah untuk dipelajari nanti dalam pendidikan mereka.

\section{Secara Efektif Mengajar Sains Anak}

Pendekatan instruksional kontemporer yang dijelaskan dalam literatur pendidikan sains sangat mengacu pada filosofi konstruktivis. Ada banyak bentuk konstruktivisme, semua aplikasi instruksional konstruktivisme yang melihat anakanak sebagai agen aktif dalam sebuah konstruksi pribadi akan pengetahuan mereka (Gunstone, 2000). Lebih lanjut, pendekatan instruksional ini bertujuan untuk mempromosikan pembelajaran aktif melalui penggunaan kegiatan langsung dengan kelompok kecil dan dengan diskusi yang masuk akal. Harapan umum adalah bahwa peserta didik lebih cenderung membangun pemahaman tentang konten sains dalam jenis lingkungan pembelajaran berbasis inkuiri ini.

Namun, pendekatan instruksional yang dipandu secara minimal, yang membebani proses kognitif peserta didik, cenderung tidak efektif dengan anakanak. Beban kognitif yang berat menyisakan sedikit kapasitas bagi anak untuk memproses informasi baru, sehingga menghambat pembelajaran (Kirschner, Sweller \& Clark, 2006; Mayer, 2004). Anak memerlukan arahan dari orang tua 
mengerjakan sesuatu, baik tugas dari sekolah maupun tugas lainnya sebab ini semua terjadi setiap anak memiliki kapasitas masing-masing dalam menghadapi informasi yang terbarukan. Cara yang paling efektif untuk mempelajari pendidikan anak kecil yaitu dengan konsep sains.

Sebuah pendekatan yang dipandu dan berbasis penyelidikan memungkinkan perancah konsep ilmiah baru dengan model mental pelajar yang ada (Trundle et al., Di pers). Dengan pendekatan inkuiri terbimbing, anak diharapkan menjadi agen aktif dalam kegiatan pembelajaran, yang memperkuat rasa kepemilikan anak dalam bekerja dan meningkatkan motivasi. Dengan pendekatan ini, anak-anak biasanya bekerja dalam kelompok kecil, yang mempromosikan keterampilan kolaborasi mereka dan memberikan kesempatan untuk memperkuat pemahaman teman sebayanya. Kegiatan sains yang bermakna, yang relevan dengan kehidupan sehari-hari anak, memungkinkan anak membuat hubungan antara apa yang telah mereka ketahui dan apa yang mereka pelajari. Diskusi yang masuk akal mempromosikan kesadaran anak-anak tentang pembelajaran dan pengembangan konsep dan memfasilitasi restrukturisasi gagasan alternatif menjadi model mental ilmiah.

Saat guru dan orang tua bekerja dengan anak-anak untuk mengembangkan keterampilan inkuiri mereka, strategi pembelajaran harus bergerak ke arah inkuiri yang lebih terbuka di mana anak-anak mengajukan pertanyaan mereka sendiri dan merancang penyelidikan mereka sendiri (Lilawati, A., 2020).

Aktivitas Sains Yang Dapat Dilakukan oleh Orangtua Di Rumah Menanyakan pertanyaan, penting untuk mendorong anak Anda untuk bertanya. Penting juga untuk mengajukan pertanyaan kepada anak Anda yang akan membuatnya berbicara tentang ide-idenya dan mendengarkan dengan cermat jawabannya. Ingatlah bahwa pengalaman anak-anak membantu mereka membentuk ide-ide mereka, ide yang mungkin, atau mungkin tidak, cocok dengan interpretasi ilmiah saat ini. Bantu anak Anda untuk melihat sesuatu dengan cara yang baru. Misalnya, terkait badai salju, Anda dapat bertanya, "Sudah Pernahkah 
Anda melihatnya bersalju di samping?" atau "Menurut Anda, apa yang terkadang menyebabkan salju turun ke samping?"

Percakapan seperti itu bisa menjadi bentuk penyelidikan atau pembelajaran yang penting. Dorong anak Anda dengan memberitahu dia bahwa tidak apa-apa membuat kesalahan atau mengakui bahwa dia tidak tahu sesuatu. Daripada mengatakan, "Tidak, itu salah", saat dia memberikan penjelasan yang salah, berikan informasi yang akurat atau bantu dia untuk menemukannya. Kembali ke badai salju, Anda dapat bertanya kepada anak Anda, "Bagaimana Anda bisa memeriksa definisi Anda?" "Bagaimana definisi kamus tentang" badai salju "sesuai dengan apa yang Anda katakan tentang salju yang bergerak ke samping?"

Mengetahui bahwa orang tua bersedia mendengarkan akan membantu anak Anda mendapatkan kepercayaan diri pada pemikirannya sendiri dan mendorong minatnya pada sains, dan mendengarkan apa yang dia katakan akan membantunya untuk mencari tahu apa yang dia ketahui dan bagaimana dia mengetahuinya.

Tangan Bekerja Dengan Baik dan Kreatif

Menyelidiki dan bereksperimen adalah cara yang bagus bagi anak-anak untuk mempelajari sains dan meningkatkan pemahaman mereka tentang ide-ide ilmiah. Sains langsung juga dapat membantu anak-anak berpikir kritis dan mendapatkan kepercayaan diri pada kemampuan mereka sendiri untuk memecahkan masalah. Anak-anak kecil secara khusus terlibat dengan hal-hal yang dapat mereka sentuh, manipulasi, dan ubah; dan dengan situasi yang memungkinkan mereka untuk mengetahui apa yang terjadi. Singkatnya, peristiwa dan teka-teki yang dapat mereka selidiki, yang merupakan inti dari studi ilmiah. Meskipun sains langsung berfungsi dengan baik, ini juga bisa menjadi berantakan dan memakan waktu. Jadi, sebelum Anda memulai, lihat apa saja yang terlibat dalam suatu kegiatan termasuk berapa lama waktu yang dibutuhkan. 
Perubahan, Keteguhan dan Pengukuran

Alam dunia terus berubah. Beberapa objek berubah dengan cepat dan beberapa terlalu lambat untuk kita amati. Anda bisa mencoba mendorong anak Anda untuk mencari perubahan dengan memintanya mengamati dan berbicara tentang:

1) Apa yang akan terjadi dengan sereal sarapan ketika kita menuangkan susu di atasnya?

2) Apa yang akan terjadi seiring waktu ketika tanaman tidak disiram atau terkena sinar matahari yang tepat?

3) Perubahan apa yang bisa dibatalkan? Setelah air diubah menjadi es batu, dapatkah diubah kembali menjadi air? Iya. Tetapi jika apel dipotong-potong, dapatkah irisan tersebut diubah kembali menjadi apel utuh

Anak-anak dapat mengamati perubahan dengan lebih cermat melalui pengukuran. Membuat diagram pertumbuhan atau membuat grafik suhu setiap hari akan melatih anak Anda untuk mencari perbedaan dan mengukurnya serta membantunya memahami bagaimana ia perlu menggunakan keterampilan matematika dalam belajar sains.

Anak-anak belajar dengan melakukan, dengan mencoba ide-ide baru dan menantang ide-ide lama. Ini tidak hanya terjadi di sekolah. Orangtua dapat membantu anak Anda belajar dengan memberinya pengalaman belajar yang aman dan menarik dalam suasana yang mendukung. Kegiatan berikut dirancang untuk digunakan bersama anak di rumah dan di komunitas. Kegiatan tersebut dimaksudkan untuk menunjukkan kepada anak bahwa sains berperan dalam banyak kegiatan sehari-hari dan digunakan di banyak tempat dan lingkungan. Mereka juga menunjukkan bahwa mempelajari sains tidak membutuhkan peralatan yang mahal dan eksperimen yang rumit.

Rumah adalah tempat yang sangat tepat bagi Anda untuk mencoba mendalami sains bersama anak. Memasukkan aktivitas sains dan bahasa ke dalam rutinitas yang biasa akan menunjukkan kepada anak Anda bagaimana sains bekerja dalam kehidupan sehari-harinya dan memberinya lingkungan yang aman untuk menjelajah dan bereksperimen. 


\section{SIMPULAN}

Selama masa pandemi COVID-19 anak sekolah dianjurkan untuk belajar di rumah. Tentu saja hal ini mengakibatkan banyak perubahan dalam berbagai bidang termasuk bidang pendidikan. Sekolah, guru, dan orangtua hendaknya memberikan dukungan sosial di rumah agar anak nyaman dalam belajar. Peran orangtua sangat penting di masa sekarang. Orangtua tidak hanya perlu mengajar berhitung, membaca, menulis saja. Ada materi lain yang harus disampaikan oleh guru dan juga orangtua di rumah, yaitu Sains. Pengalaman sains yang menarik memungkinkan untuk pengembangan pemikiran ilmiah. Anak-anak membutuhkan pengalaman sains yang berkualitas selama tahun-tahun masa kecil mereka.

Sains dan Literasi menyediakan kerangka kerja instruksional yang sistematis, kurikulum berbasis standar, dan sumber daya guru yang berkualitas tinggi. Kegiatan ini juga secara efektif mengintegrasikan teks, ilustrasi, dan diagram ke dalam instruksi berbasis inkuiri. Ada banyak kegiatan yang dapat dilakukan dalam mengajarkan sains kepada anak, seperti menanyakan berbagai pertanyaan berhubungan dengan sains dan melatih keterampilan tangan. Anak-anak belajar dengan melakukan, dengan mencoba ide-ide baru dan menantang ide-ide lama. Ini tidak hanya terjadi di sekolah. Orangtua dapat membantu anak Anda belajar dengan memberinya pengalaman belajar yang aman dan menarik dalam suasana yang mendukung. Kegiatan berikut dirancang untuk digunakan bersama anak di rumah dan di komunitas. Rumah adalah tempat yang tepat bagi orangtua untuk mulai mencoba pembelajaran sains bersama anak.

\section{REFERENSI}

Ahn, J. C. (2018). Designing public, tangible displays to connect youth learning across settings. Proceeding of the 2018 CHI Conference on Human Factors in Computing Systems , 1-12.

Bar, V., \& Galili, I. (1994). Stages of children's views about evaporation. International Journal of Science Education, 16(2), 157-174.

Bayrakdar, S. \&. (2020). Inequalities in home learning and schools' provision of distance teaching during school closure of COVID-19 lockdown in the UK (No.2020-09). ISER Working Paper Series. 
Bredekamp, S. (1993). The relationship between early childhood education and early childhood special education: Healthy marriage or family feud?. Topics in Early Childhood Special Education, 13(3), 258-273.

Cahyati, N. \&. (2020). Peran Orang Tua dalam Menerapkan Pembelajaran di Rumah Saat Pandemi Covid-19. Jurnal Golden Age , 4(01), 152-159.

Dahl, R. E. (2018). Importance of Investing in adolescence from a developmental science perspective. Nature, 441-450.

Darin E. Hartley. 2001. Selling e-learning, American Society for Training and Development,

Darling-Hammond, L., Flook, L., Cook-Harvey, C., Barron, B., \& Osher, D. (2020). Implications for educational practice of the science of learning and development. Applied Developmental Science, 24(2), 97-140.

Driver, R., Guesne, E. \& Tiberghien, A. (1985). Some features of children's ideas and their implications for teaching. In Driver, R., Guesne, E. \& Tiberghien, A. (Eds.), Children's ideas in science. (pp. 193-201). Philadelphia: Open University Press.

Eshach, H., \& Fried M. N. (2005). Should science be taught in early childhood? Journal of Science Education and Technology, 14(3), 315-336.

Fadlilah, A. N. (2020). Strategi menghidupkan motivasi belajar anak usia dini selama pandemi covid-19 melalui publikasi. Jurnal Obsesi: Jurnal Pendidikan Anak Usia Dini , 5(1), 373-384.

Handarini, O. I. (2020). Pembelajaran Daring Sebagai Upaya Study From Home (SFH) Selama Pandemi Covid 29. Jurnal Pendidikan Administrasi Perkantoran (JPAP) , 496-503.

Iftitah, S. L. (2020). Peran Orang Tua Dalam Mendampingi Anak di Rumah Selama Pandemi COVID-19. JCE (Journal of Childhood Education) , 4(2), 71-81.

Kartika Sari, Y. (2020). Peran Orang Tua Dalam Meningkatkan Minat Belajar Anak Usia Dini. (Master's Skripsi). Universitas Islam Negeri Sultan Syarif Kasim Riau

Ningrum, L. K. (2019). Peran Orang Tua Dalam Meningkatkan Motivasi Belajar Anak di Kelurahan Margorejo 25 Polos Kecamatan Metro Selatan (Doctoral dissertation, IAIN Metro).

Lilawati, A. (2020). Peran Orang Tua dalam Mendukung Kegiatan Pembelajaran di Rumah pada Masa Pandemi.Jurnal Obsesi: Jurnal Pendidikan Anak Usia Dini, 5(1), 549-558.

Mahmudah, L. (2017). Pentingnya pendekatan keterampilan proses pada pembelajaran IPA di Madrasah. ELEMENTARY: Islamic TeacherJournal , 4(1).

National Science Foundation. (2001). Science and engineering degrees, by race/ ethnicity of recipients: 1990-1998. Arlington, VA: Author.

Nugraha, A. J. (2017). Analisis kemampuan berpikir kritis ditinjau dari keterampilan proses sains dan motivasi belajar melalui model pbl. Journal of Primary Education, 35-43.

Osborne, R. \& Freyberg, P. 1985. Learning in Science: The Implications of Tobin, K., Tippins, J. and Gallard, A.J. Clñldren's Science. Published by 1994. Research on Instructional Heinemann Education. 